\title{
Pengaruh Pemberian Pupuk Kompos dan Mikoriza Terhadap Pertumbuhan Bibit Kelapa Sawit (Elaeis guineensis Jacq.)
}

\section{The Effect of Compost Fertilizer and Mycorrhiza on the Growth of Palm Oil Seedling (Elaeis guineensis Jacq.)}

\author{
Vini Masyitoh Lubis ${ }^{1}$, Agam Ihsan Hereri ${ }^{1}$, Ashabul Anhar ${ }^{1 *}$ \\ ${ }^{1}$ Program Studi Agroteknologi, Fakultas Pertanian, Universitas Syiah Kuala
}

\begin{abstract}
Abstrak. Penelitian ini bertujuan untuk mengetahui manfaat penggunaan pupuk kompos dan mikoriza dalam menunjang pertumbuhan bibit kelapa sawit. Peneltian ini dilaksanakan di Kebun Percobaan 2 dan Laboratorium Hortikultura Fakultas Pertanian Universitas Syiah Kuala, Banda Aceh dari bulan Juli sampai Oktober 2018. Penelitian ini menggunakan Rancangan Acak Kelompok pola faktorial 3x3 dan 3 ulangan, sehingga terdapat 27 satuan percobaan dan dilanjutkan dengan uji Beda Nyata Jujur taraf 5\% pada hasil uji $\mathrm{F}$ yang signifikan. Faktor pertama adalah pemberian pupuk kompos dengan 3 taraf yaitu: tanpa pupuk kompos $\left(\mathrm{K}_{0}\right), 20 \%$ pupuk kompos $\left(\mathrm{K}_{1}\right)$, dan $40 \%$ kompos $\left(\mathrm{K}_{2}\right)$. Faktor kedua adalah dosis mikoriza dengan 3 taraf yaitu 0 , 20, dan 40 g/polybag. Peubah yang diamati adalah tinggi bibit, diameter pangkal batang, berat berangkasan basah, berat berangkasan kering, panjang akar, berat basah akar, berat kering akar, persentasi akar terkolonisasi mikoriza. Hasil penelitian menunjukkan bahwa, perlakuan pupuk kompos berpengaruh tidak nyata terhadap semua peubah yang diamati. Pemberian beberapa dosis mikoriza berpengaruh sangat nyata terhadap persentase akar terkolonisasi mikoriza dan berpengaruh tidak nyata terhadap tinggi bibit, diameter pangkal batang, berat berangkasan basah, berat berangkasan kering, panjang akar, berat basah akar, dan berat kering akar. Terdapat interaksi yang nyata antara perlakuan pupuk kompos $\mathrm{K}_{2}$ dan mikoriza $0 \mathrm{~g} /$ polybag $\left(\mathrm{M}_{0}\right)$.
\end{abstract}

Kata kunci :, Bibit Kelapa Sawit, Mikoriza, dan Pupuk kompos

Abstract. The research aims to determine the benefits of using compost fertilizer and mycorrhiza in supporting the growth of oil palm seedlings. This research was carried out at the Experimental Garden 2 and Horticulture Laboratory of the Faculty of Agriculture, Syiah Kuala University, Banda Aceh from July to October 2018. This research used a Randomized Block Design with $3 \times 3$ with 3 replication so, there were 27 experimental units and continued with Honestly Significant Difference tests level of $5 \%$ on a significant $\mathrm{F}$ test result. The first factor was the concentration of compost fertilizer with 3 treatments: Without compost fertilizer $\left(\mathrm{K}_{0}\right)$, $20 \%$ compost fertilizer $\left(\mathrm{K}_{1}\right)$, and $40 \%$ compost fertilizer $\left(\mathrm{K}_{2}\right)$. The second factor was mycorrhiza dose with 3 treatments: 0,20 and $40 \mathrm{~g} / \mathrm{polybag}$. The variables observe were seedling height, stem base diameter, plant fresh weight, plant dry weight, root length, root fresh weight, root dry weight, the percentage of mycorrhiza colonized roots. The results of this research showed that the composition of the compost fertilizer media was not significant on all variabels observed. Several doses of mycorrhizawere very significant on the percentage of mycorrhiza colonized roots and not significant effect on seedling height, stem base diameter, plant fresh weight, plant dry weight, root length, root fresh weight, and root dry weight. There was significant interaction in compost fertilizer $\mathrm{K}_{2}$ and mycorrhiza $0 \mathrm{~g} /$ polybag $\left(\mathrm{M}_{0}\right)$.

Keyword : Compost, Mycorrhiza, Palm Oil Seed

\section{PENDAHULUAN}

Tanaman kelapa sawit (Elaeis guineensis Jacq.) merupakan tanaman yang tergolong dalam famili palmae dari daerah tropis. Indonesia mengenal kelapa sawit sejak tahun 1848 dan berasal dari Afrika. Sejak tahun 1911 kelapa sawit mulai diusahakan secara komersil di Indonesia. Kelapa sawit saat ini menduduki posisi penting di sektor perkebunan, karena 
kelapa sawit menghasilkan nilai ekonomi tinggi dan kelapa sawit menghasilkan minyak atau lemak (Balai Informasi Pertanian, 1990).

Kelapa sawit merupakan komoditas yang menyumbang devisa paling besar bagi Indonesia. Sekitar 12.307.677 Ha luas areal dengan produksi kelapa sawit 35.359.384 ton (Statistik Pusat Direktorat Jenderal Perkebunan 2017). Perkebunan kelapa sawit sebagian besar diusahakan oleh perkebunan swasta yakni 6,7 juta Ha, sedangkan perkebunan rakyat mengelola 4,7 juta Ha dan hanya 747.498 Ha yang dikelola oleh perusahan perkebunan negara (PTPN) (Direktorat Jenderal Perkebunan, 2017).

Produktivitas kelapa sawit di Indonesia masih berpotensi untuk ditingkatkan lagi dengan beberapa cara, salah satunya adalah menggunakan bahan tanam yang unggul dan bermutu, serta perbaikan teknik budidaya yang lebih efektif dan efesien. Persiapan bahan tanam berupa bibit merupakan tahap awal yang menjadi aspek penting dalam upaya memperoleh tanaman kelapa sawit dengan produktivitas optimal (Sukamto, 2008).

Tersedianya bibit sehat dan unggul merupakan aspek yang perlu diperhatiankan sebagai penunjang produksi. Peggunaan bibit sangat menentukan keberhasilan dalam pembudidayaan kelapa sawit (PPKS, 2006).

Keadaan bibit yang baik akan mempengaruhi pencapaian hasil produksi dari kelapa sawit secara optimum. Perolehan kualitas bibit kelapa sawit yang jagur diawali dengan menggunakan benih unggul dan bermutu, pemeliharaan yang tepat dan optimal sangat diperlukan tanaman muda (bibit) agar dapat tumbuh dengan baik. Salah satu kegiatan tersebut adalah pemberian nutrisi (pupuk) pada bibit secara tepat jenis, waktu, dosis dan cara. Pupuk organik dan anorganik merupakan jenis pupuk yang digunakan untuk menambah hara bagi tanaman (Sutanto, 2003).

Sekitar 20\% - 27\% ketersdian tandan buah segar (TBS) merupakan hasil olahan limbah organik (limbah tandan kosong kelapa sawit). Unsur hara N 1,5\%; P 0,3\%; $\mathrm{K}$ 2,00\%; Ca 0,72\%; $\mathrm{Mg} 0,4$; kadar air 45-50\% dan ertumbuhan bibit kelapa sawit organik 50\%; C/N 15,03\% merupakan unsur hara yang dikandung oleh tandan kosong kelapa sait (TTKS) yang dapat diolah menjadi pupuk kompos (PPKS, 2008).

Menurut Novriani (2010) dari hasil penelitiannya mengenai aplikasi kompos $30 \%$ nyata meningkatkan serapan hara $\mathrm{N}(163,84 \%)$, kolonisasi mikoriza pada akar $(83,23 \%)$, berat kering tajuk $(163,27 \%)$, serapan hara $\mathrm{P}(153,67 \%)$, berat kering akar $(141,86 \%)$, dan berat kering total tanaman $(156,74 \%)$ pada tanaman kelapa sawit dibandingkan tanpa kompos. Hasil penelitian Hendra (2012) menyatakan bahwa campuran perlakuan medium topsoil + kompos TKKS 1:1 dengan tanpa pemberian pupuk majemuk, memperlihatkan pertambahan bobot kering yang lebih tinggi pada petumbuhan bibit kelapa sawit.

Selain penggunaan kompos, Fungi mikoriza arbuskular (FMA) dapat digunakan sebagai pembantu dalam menyerapan unsur hara lebih optimal. Dalam mengurangi penggunaan pupuk anorganik belakangan ini mulai digunakan FMA oleh petani. Keuntungan dari penggunaan fungi ini antara lain dapat membantu tanaman dalam menyerap unsur hara dan air dari tanah, meningkatkan toleransi tanaman pada cekaman biotik dan abiotik, pemberian cukup sekali seumur hidup tanaman, dan memberikan manfaat pada rotasi tanaman berikutnya (Treseder, 2013).

Fungi mikoriza arbuskular merupakan suatu bentuk simbiosis antara jamur dan akar tumbuhan yang menunjukkan adanya interaksi fungsional yang saling menguntungkan. Simbiosis ini bersifat saling menguntungkan karena fungi mendapatkan senyawa karbon 
organik dari tanaman inang dan sebaliknya fungi membantu akar tanaman menyerap unsur hara yang bersifat tidak mobile di dalam tanah seperti P, Zn, Fe dan hifa yang berkembang di dalam tanah secara langsung dapat memperbaiki sifat fisik tanah melalui perbaikan agregat tanah (Listyowati, 2013). Hifa juga dapat membantu tanaman menyerap air di tanah yang jauh lebih efisien dibandingkan dengan rambut akar (Smith dan Read, 2008).

Hasil penelitian yang dilakukan oleh Hamzah (2011) menyatakan bahwa penggunaan Fungi mikoriza arbuskular dengan dosis 20 gram per polybag yang dikombinasi menggunakan pupuk NPK mutiara dengan dosis 10 gram per polybag memberikan respon pertumbuhan terbaik terhadap bibit kelapa sawit. Hasil Penelitian Novriani (2010) menyatakan bahwa $10 \mathrm{~g}$ mikoriza yang diaplikasikan dapat meningkatkan persen kolonisasi mikoriza pada akar $(82,96 \%)$, berat kering total $(84,29 \%)$, berta kering akar $(84,21 \%)$ pada tanaman kelapa sawit dibandingkan tanpa mikoriza.

Berdasarkan hal tersebut perlu dilakukan penelitian lanjutan mengenai reaksi pertumbuhan bibit kelapa sawit akibat pemberian Fungi mikoriza arbuskular yang dikombinasikan dengan pupuk organik seperti pupuk kompos.

\section{METODE PENELITIAN}

\section{Waktu dan Tempat}

Pelakasaan penelitian dilakukan pada bulan 14 Juli sampai 14 Oktober di kebun percobaan, Laboratorium Fisiologi Tumbuhan, dan Laboratorium Hortikultura Jurusan Agroteknologi Universitas Syiah Kuala.

\section{Alat dan Bahan}

Alat yang digunakan pada penelitian ini adalah timbangan digital (Ken $E W$ ), jangka sorong (Vernier Caliper), ayakan tanah ukuran 6 mesh, cangkul, meteran, gembor, oven, pisau, mikroskop cahaya, botol, gelas ukur volume $1000 \mathrm{ml}$, magnetic stirrer with hotplate (bioSan), beaker glass volume $1000 \mathrm{ml}$, pinset, suntik, gunting kertas, hansprayer volume $2000 \mathrm{ml}$, alat tulis dan kamera.

Bahan yang digunakan dalam penelitian ini berupa tanah, polybag (volume $3 \mathrm{~kg}$ ) dan paranet (ukuran panjang $14 \mathrm{~m}$, dan lebar $5 \mathrm{~m}$ ), pupuk kompos tandan kosong kelapa sawit (TKKS) yang diperoleh dari PT. Tasmapuja Riau yang dibutuhkan $81 \mathrm{~kg}$, bibit kelapa sawit jenis D x P (SM B) umur 3 bulan sebanyak 81 bibit kelapa sawit, Inokulan fungi Mikoriza (FMA) dari PT. INTI AGRO LESTARI Bogor sebanyak $2 \mathrm{~kg}$, pupuk NPK mutiara (16:16:16) toko pertanian di Tungkop sebanyak 5 gram, yang dibutuhkan sebanyak 5 gram, $\mathrm{KOH} \mathrm{10 \%} \mathrm{sebanyak} 5$ gram, aquades, asam cuka, tinta quink parker dan ketas label.

\section{Rancangan Penelitian}

Penelitian ini menggunakan Rancangan Acak Kelompok (RAK) pola faktorial yang terdiri atas 2 (dua) faktor dengan pola $3 \times 3$ dengan 3 ulangan sehingga terdapat 27 satuan percobaan. Faktor pertama adalah pemberian Pupuk Kompos (K), terdiri atas 3 taraf yaitu: tanpa pupuk kompos $\left(\mathrm{K}_{0}\right.$, kontrol), $20 \%$ pupuk kompos $\left(\mathrm{K}_{1}\right)$, dan $40 \%$ pupuk kompos 
$\left(\mathrm{K}_{2}\right)$. Faktor kedua adalah dosis Mikoriza $(\mathrm{M})$ yang terdiri atas 3 taraf yaitu: $0 \mathrm{~g} /$ polybag $\left(\mathrm{M}_{0}\right.$, kontrol), $20 \mathrm{~g} /$ polybag $\left(\mathrm{M}_{1}\right)$, dan $40 \mathrm{~g} /$ polybag $\left(\mathrm{M}_{2}\right)$.

\section{Pelaksanaan Penelitian \\ Persiapan Media Tanam}

Media tanam yang digunakan adalah tanah dan pupuk kompos. Media tanam yang sudah dipersiapkan tersebut dimasukkan ke dalam polybag volume $5 \mathrm{~kg}$. Bibit kelapa sawit yang masih di dalam tempat pembibitan awal di pindahkan ke dalam polybag isi $5 \mathrm{~kg}$.

\section{Perlakuan Pupuk Kompos}

Pupuk kompos diberikan sekali pada saat pengisian media tanam dengan cara mencampurkan pupuk kompos dan tanah sesuai dengan perlakuan yaitu tanpa pupuk kompos, $20 \%$ pupuk kompos dan $40 \%$ pupuk kompos.

\section{Pembuatan Naungan}

Naungan dibuat agar bibit terhinda dari paparan sinar matahari dan air hujan. Panjang naungan yang dibuat $14 \mathrm{~m}$, tinggi $2 \mathrm{~m}$ dan lebar $5 \mathrm{~m}$ dengan tiang yang terbuat dari bambu dan atap dari paranet.

\section{Persiapan Bibit}

Bibit kelapa sawit yang sudah berumur 3 bulan atau telah berdaun 3-4 helai yang diperoleh dari pusat penelitian kelapa sawit (PPKS) Marihat dan disemai di desa shioum Kecamatan Indrapuri. Pemeliharaan yang dilakukan yaitu penyiraman pada pagi dan sore hari, penyiangan gulma dan sanitasi di lapangan.

\section{Perlakuan Fungi Mikoriza Arbuskula}

Setiap polybag diberikan inokulan fungi Mikoriza arbuskula sesuai perlakuan masing-masing sebanyak 0, 20, dan 40 g/polybag. Sebelumnya mikoriza ditimbang dengan menggunakan timbangan digital di Laboraturium Hortikultura Fakultas Pertanian Unsyiah. Inokulan Mikoriza ditaburkan pada lubang tanam disekitar daerah perakaran pada kedalaman $10 \mathrm{~cm}$ sesuai perlakuan. Aplikasi Mikoriza asburkula dilakukan sekali pada saat tanam.

\section{Pemupukan}

Pemberian pupuk dasar NPK Mutiara sebanyak 5 g/polybag diberikan 7 hari sebelum inokulasi inokulum mikoriza.

\section{Penanaman Bibit}

Bibit dipindahkan ke dalam polybag penanaman yang sebelumnya telah diberikan mikoriza. Tanah pada sekitar bibit dikikis untuk memudahkan penanaman bibit kemudian akar bibit dilukai dengan cara dipotong sekitar $3 \mathrm{~cm}$. Bibit yang telah siap kemudian dimasukkan tepat dibagian tengah polybag dan ditutup kembali dengan tanah.

\section{Pemeliharaan}

Penyiangan dan pengendalian hama dan penyakit merupakan salah satu kegiatan dalam pemeliharaan tanaman, kemudian penyiraman dan penyiangan meliputi kegiatan 
pemeliharaan. Penyiraman dilakukan dua kali sehari yaitu pagi dan sore hari atau disesuaikan dan penyiangan gulma dilakukan secara manual dengan kondisi di lapangan. Pengendalian hama dan penyakit dilakukan jika tanaman mulai terserang.

Pengendalian penyakit yang menyerang pada bibit kelapa sawit yaitu Curvularia (bercak daun) dan Antraknosa dikendalikan dengan menggunakan Dithane M-45/80 WP (konsentrasi $0.15 \%-0.2 \%$ ) dengan interval penyemprotan 7-10 hari. Sedangankan hama yang menyerang pada bibit kelapa sawit yaitu belalang dikendalikan dengan menggunakan Sidamethrin (bahan aktif : sipermetrin $50 \mathrm{~g}^{-1}$ ).

\section{Pembongkaran Bibit}

Proses pembongkaran bibit dilakukan di akhir penelitian yaitu dengan cara membongkar bibit dan dibersihkan dari sisa-sisa tanah dengan tujuan untuk mengamati peubah berat berangkasan basah, berat berangkasan kering, panjang akar, berat basah akar, berat kering akar, dan persentasi akar terkolonisasi mikoriza.

\section{Peubah Pengamatan}

Peubah yang diamati pada penelitian ini yaitu tinggi bibit umur 30, 60, dan 90 HST, diameter pangkal batang 30, 60, dan 90 HST, berat berangkasan basah, berat berangkasan kering, panjang akar, berat basah akar, berat kering akar, dan persentasi akar terkolonisasi mikoriza.

\section{HASIL DAN PEMBAHASAN}

\section{Hasil Penelitian}

\section{Pengaruh Pemberian Pupuk Kompos terhadap Pertumbuhan Bibit Kelapa Sawit}

Rata-rata pertumbuhan bibit kelapa sawit akibat perlakuan pemberian pupuk kompos dapat dilihat pada Tabel 1.

Tabel 1. Rata-rata Pertumbuhan Bibit Kelapa Sawit Akibat Perlakuan Pemberian Pupuk Kompos

\begin{tabular}{lccc}
\hline \multicolumn{1}{c}{ Peubah } & \multicolumn{3}{c}{ Pupuk Kompos } \\
\cline { 2 - 4 } & Kontrol & $20 \%$ & $40 \%$ \\
& $\left(\mathrm{~K}_{0}\right)$ & $\left(\mathrm{K}_{1}\right)$ & $\left(\mathrm{K}_{2}\right)$ \\
\hline Tinggi Bibit 30 HST & 41,66 & 41,93 & 38,82 \\
Tinggi Bibit 60 MST & 43,48 & 44,15 & 44,05 \\
Tinggi Bibit 90 HST & 48,68 & 49,94 & 50,48 \\
Diameter Pangkal Batang 30 HST & 10,48 & 10,56 & 10,87 \\
Diameter Pangkal Batang 60 HST & 16,76 & 16,76 & 16,65 \\
Diameter Pangkal Batang 90 HST & 19,36 & 16,76 & 16,65 \\
Berat Berangkasan Basah & 82,24 & 84,48 & 83,15 \\
Berat Berangkasan Kering & 21,53 & 22,65 & 23,28 \\
Panjang Akar & 47,56 & 45,19 & 47,44 \\
Berat Basah Akar & 25,05 & 25,74 & 26,50 \\
Berat Kering Akar & 7,41 & 7,61 & 7,85 \\
PersentaseAkar Terkolonisasi Mikoriza & 30,65 & 26,98 & 27,87 \\
\hline
\end{tabular}

Tabel 1 menunjukkan bahwa, tinggi bibit, diameter pangkal batang, berat berangkasan basah, berat berangkasan kering, panjang akar, berat basah akar, berat kering 
akar, dan persentase akar terkolonisasi mikoriza pada perlakuan pupuk kompos berpengaruh tidak nyata, akan tetapi pertumbuhan bibit kelapa sawit cenderung lebih baik pada pupuk kompos $40 \%$ pupuk kompos $\left(\mathrm{K}_{2}\right)$.

\section{Pengaruh Pemberian Mikoriza terhadap Pertumbuhan Bibit Kelapa Sawit}

Rata-rata pertumbuhan bibit kelapa akibat perlakuan dosis Mikoriza dapat dilihat pada Tabel 2.

Tabel 2. Rata-rata Pertumbuhan Bibit Kelapa Akibat Perlakuan Dosis Mikoriza

\begin{tabular}{lcccc}
\hline \multicolumn{1}{c}{ Peubah } & \multicolumn{3}{c}{ Dosis Mikoriza (g/polybag) } & $\mathrm{BNJ}_{0,05}$ \\
\cline { 2 - 3 } & 0 & 20 & 40 & \\
\hline Tinggi Bibit 30 HST & $\left(\mathrm{M}_{0}\right)$ & $\left(\mathrm{M}_{1}\right)$ & $\left(\mathrm{M}_{2}\right)$ & - \\
Tinggi Bibit 60 MST & 41,70 & 38,02 & 42,69 & - \\
Tinggi Bibit 90 HST & 43,87 & 43,44 & 44,37 & - \\
Diameter Pangkal Batang 30 HST & 50,66 & 48,96 & 49,47 & - \\
Diameter Pangkal Batang 60 HST & 10,60 & 10,66 & 10,66 & - \\
Diameter Pangkal Batang 90 HST & 16,49 & 16,97 & 16,71 & - \\
Berat Berangkasan Basah & 20,17 & 19,26 & 18,26 & - \\
Berat Berangkasan Kering & 82,85 & 84,47 & 82,55 & - \\
Panjang Akar & 22,94 & 23,50 & 22,02 & - \\
Berat Basah Akar & 47,05 & 48,59 & 44,54 & - \\
Berat Kering Akar & 25,50 & 28,02 & 23,77 & 10,90 \\
Persentasi Akar Terkolonisasi Mikoriza & 8,22 & 8,03 & 6,61 & -
\end{tabular}

Keterangan : Angka yang diikuti oleh huruf yang sama pada kolom yang sama berbeda tidak nyata pada taraf $0.05(\mathrm{Uji} \mathrm{BNJ})$

Tabel 2 menunjukkan bahwa, persentase akar bibit kelapa sawit terkolonisasi mikoriza pada dosis mikoriza $20 \mathrm{~g} /$ polybag $\left(\mathrm{M}_{1}\right)$ berbeda sangat nyata dengan perlakuan dosis $0 \mathrm{~g} /$ polybag $\left(\mathrm{M}_{0}\right)$, namun tidak berbeda nyata dengan dosis $40 \mathrm{~g} /$ polybag $\left(\mathrm{M}_{2}\right)$. Pertumbuhan bibit kelapa sawit yang lebih baik dijumpai pada dosis $20 \mathrm{~g} /$ polybag $\left(\mathrm{M}_{1}\right)$.

\section{Pengaruh Interaksi antara Pemberian Pupuk Kompos dan Mikoriza terhadap Pertumbuhan Bibit Kelapa Sawit}

Hasil uji $\mathrm{F}$ pada analisis ragam menunjukkan bahwa interaksi yang nyata antara pupuk kompos dengan mikoriza terhadap diameter pangkal batang bibit kelapa sawit pada umur 30 HST. Rata-rata diameter pangkal bibit kelapa sawit umur 30 HST pada pemberian pupuk kompos dan mikoriza setelah diuji dengan $\mathrm{BNJ}_{0,05}$ disajikan pada Tabel 3 .

Tabel 3. Rata-rata Diameter Pangkal Batang Bibit Kelapa Sawit Umur 30 HST pada Pemberian Pupuk Kompos dan Mikoriza

\begin{tabular}{lccccc}
\hline Peubah & $\begin{array}{c}\text { Dosis Mikoriza } \\
(\mathrm{g} / \text { polybag })\end{array}$ & \multicolumn{3}{c}{ Pupuk Kompos } & BNJ \\
\cline { 3 - 5 } & $\mathrm{K}_{0}$ & $10.08 \mathrm{Aa}$ & $9.83 \mathrm{Aa}$ & $11.88 \mathrm{Bb}$ & \\
\hline Diameter & $\mathrm{K}_{1}$ & $10.59 \mathrm{Aa}$ & $10.91 \mathrm{Aa}$ & $10.47 \mathrm{Aab}$ & 1.42 \\
Pangkal Batang & $\mathrm{M}_{2}$ & $10.78 \mathrm{Aa}$ & $10.94 \mathrm{Aa}$ & $10.27 \mathrm{Aa}$ & \\
30 HST & & &
\end{tabular}

Keterangan: Angka yang diikuti oleh huruf yang sama berbeda tidak nyata pada taraf BNJ0.05. Huruf kapital merupakan notasi horizontal, huruf kecil merupakan notasi vertikal. 
Tabel 3 menunujkkan $40 \%$ pupuk kompos $\left(\mathrm{K}_{2}\right)$ menghasilkan diameter pangkal batang bibit kelapa sawit terbaik pada penggunaan dosis mikoriza $0 \mathrm{~g} /$ polybag $\left(\mathrm{M}_{0}\right)$ yang berbeda nyata dengan perlakuan tanpa pupuk kompos $\left(\mathrm{K}_{0}\right)$ dan $20 \%$ pupuk kompos $\left(\mathrm{K}_{1}\right)$. Pada 20\% Pupuk kompos $\left(\mathrm{K}_{1}\right)$ menghasilkan diameter pangkal batang bibit kelapa sawit terbaik pada penggunaan dosis mikoriza $20 \mathrm{~g} /$ polybag namun tidak berbeda nyata pada tanpa pupuk kompos $\left(\mathrm{K}_{0}\right)$ dan $40 \%$ pupuk kompos $\left(\mathrm{K}_{2}\right)$.

Kombinasi terbaik dijumpai pada perlakuan $40 \%$ pupuk kompos $\left(\mathrm{K}_{2}\right)$ dengan perlakuan tanpa mikoriza $\left(\mathrm{M}_{0}\right)$ yaitu $\mathrm{K}_{2} \mathrm{M}_{0}$ sebesar $11.88 \mathrm{~mm}$ yang tidak berbeda nyata dengan kombinasi perlakuan $\mathrm{K}_{2} \mathrm{M}_{1}$ tetapi berbeda nyata dengan kombinasi perlakuan lainnya.

\section{Pembahasan}

\section{Pengaruh Pemberian Pupuk Kompos terhadap Pertumbuhan Bibit Kelapa Sawit}

Berdasarkan beberapa pemberian pupuk kompos yang diaplikasikan pada penelitian ini, pertumbuhan bibit kelapa sawit cenderung lebih baik dijumpai pada pemberian $40 \%$ pupuk kompos $\left(\mathrm{K}_{2}\right)$ terhadap peubah pengamatan tinggi bibit kelapa sawit, berat berangkasan kering bibit kelapa sawit, berat basah akar bibit kelapa sawit dan berat kering akar bibit kelapa sawit. Pemberian kompos TKKS dapat meningkatkan jumlah/kandungan hara yang terserap oleh tananam, sehingga dapat meningkatkan pertumbuhan tanaman kelapa sawit. Berdasarkan hasil kandung pupuk kompos TKKS yang terkandung (Lampiran 2) N-total (2,54 \%), N-NH $(2,38 \%), \mathrm{N}^{-N_{3}}(0,08 \%), \mathrm{P}(0,25 \%), \mathrm{K}(0,82 \%)$, $\mathrm{Mg}(0,45 \%), \mathrm{Ca}(0,84 \%), \mathrm{Fe}(1,85 \%)$, bahan organik (62,7 \%), C/N ratio (14,9\%), dan pH (7,29 \%). Hal ini sesuai dengan Ryan (2009) yang menyatakan bahwa TKKS yang dijadikan pupuk kompos sangat kaya akan unsur hara seperti $\mathrm{N}, \mathrm{P}, \mathrm{K}$, dan $\mathrm{Mg}$ yang dapat memenuhi kebutuhan unsur hara bagi tanaman.

Simamora dan Salundik (2006) menyatakan bahwa kompos mengandung unsur hara yang kompleks (makro dan mikro) walaupun dalam jumlah yang sedikit, kompos dapat meningkatkan ketersediaan hara dan humat, ketersedian kapasitas tukar kation, dan melindungi perakaran tanaman dari patogen.

Gardner et al. (2001) menyatakan bahwa berat kering yang terbentuk mencerminkan banyaknya fotosintat sebagai hasil fotosintesis dan akumulasi senyawa organik yang berhasil disintesis tanaman dari senyawa anorganik yaitu air dan $\mathrm{CO}_{2}$.

Deswenti (2011) menyatakan bahwa kompos TKKS yang digunakan mengandung unsur P sebesar 0,25 \% sehingga berpengaruh terhadap perkembangan akar bibit kelapa sawit karena unsur P dalam pembentukan akar. Marsono (2001) menambahkan bahwa fosfor berguna untuk membantu asimilasi dan respirasi, mempercepat proses pembungaan, pembuahan, pemasakan biji dan buah.

Hendra Luma (2012) menyatakan bahwa pemberian kompos TKKS ke media tanam dapat memperbaiki aerasi pada media, sehingga memberikan kondisi yang baik untuk pertumbuhan dan perkembangan akar, dan penyerapan unsur hara dan air. Diameter pangkal batang juga dapat dijadikan tolak ukur untuk pertumbuhan bibit kelapa sawit yang baik, yang pada dasarnya semakin besar perkembangan pangkal batang maka keadaan organ-organ dibagian atasnya seperti tinggi batang dan jumlah pelepah daun juga semakin baik pula. 


\section{Pengaruh Pemberian Mikoriza terhadap Pertumbuhan Bibit Kelapa Sawit}

Berdasarkan beberapa dosis mikoriza yang diaplikasikan pada penelitian ini, pertumbuhan bibit kelapa sawit cenderung lebih baik dijumpai pada dosis $20 \mathrm{~g} / \mathrm{polybag}$ $\left(\mathrm{M}_{1}\right)$ terhadap berat berangkasan basah bibit kelapa sawit, berat berangkasan kering bibit kelapa sawit, panjang akar bibit kelapa sawit, berat basah akar bibit kelapa sawit, dan persentase akar bibit kelapa sawit terkolonisasi mikoriza. Sedangkan perlakuan dengan dosis kontrol $0 \mathrm{~g} /$ polybag $\left(\mathrm{M}_{0}\right)$ menunjukkan pengaruh terbesar terhadap tinggi bibit kelapa sawit, diameter pangkal batang bibit kelapa sawit dan berat kering akar bibit kelapa sawit.

Secara keseluruhan pemberian mikoriza berpengaruh tidak nyata terhadap semua peubah yang diamati. Berdasarkan analisis tanah kandungan fosfor yang tersedia ditanah yaitu $24,65 \mathrm{mg} \mathrm{kg}^{-1}$ hal ini diduga bahwa unsur $\mathrm{P}$ sudah tercukupi bagi pertumbuhan tanaman. Oleh karena itu, kemampuan mikoriza untuk melarutkan $\mathrm{P}$ tidak maksimal karena unsur $\mathrm{P}$ sudah dalam bentuk tersedia bagi tanaman. Hal ini juga dikarenaka adanya penambahan pupuk NPK pada media tanam sebagai pupuk dasar.

Simbiosis antara fungi mikoriza arbuskula (FMA) dan akar tanaman tidak selalu bersimbiosis secara efektif. Simbiosis ini dapat terjadi dengan efektif ketika unsur P didalam tanah kurang tersedia dan penurunan efektivitas simbiosis dapat terjadi jika unsur $\mathrm{P}$ didalam tanah meningkat (Schubert dan Hayman 1978). Pernyataan yang sama dikemukan oleh De Miranda et al. (1989) bahwa penambahan pupuk P pada tanah mengakibatkan penundaan infeksi akar oleh FMA, sehingga persentase infeksi akar rendah. Menurut Swift (2004) menyatakan bahwa pembentukan simbiosis mikoriza terjadi secara maksimum seandainya unsur P yang terkandung didalam tanah tidak lebih dari 50 part per million (ppm). Pada analisis tanah kadar P terdesia didalam tanah yaitu 240,65 ppm.

Berdasarkan pada peubah tinggi tanaman (tabel 2) menunjukkan bahwa tidak didapati perbedaan yang nyata antara tanaman yang diujikan. Hal ini sejalan dengan pernyataan Harahap et al. (2014) menyatakan bahwa tidak maksimalnya asosiasi antara mikoriza yang diinokulasikan dengan inangnya, menyebabkan kurangnya penyerapan unsur hara sehingga tanaman yang dihasilkan juga memiliki tinggi tanaman yang relatif sama.

Fakuara (1998) menyatakan bahwa pemberian unsur fosfor yang berlebihan dapat menghambat kolonisasi cendawan. Beberapa faktor yang lain yang dapat mempengaruhi pertumbuhan dan perkembangan mikoriza adalah $\mathrm{pH}$, pengapuran, dan penggunaan pestisida.

Pemberian mikoriza berpengaruh sangat nyata pada persentase akar bibit kelapa sawit terkolonisasi mikoriza. Pada perlakuan $20 \mathrm{~g} /$ polybag $\left(\mathrm{M}_{1}\right)$ menghasilkan rata-rata persentase akar bibit kelapa sawit terkolonisasi mikoriza tertinggi yaitu 42,67\%. Menurut Widiastuti et al. (2003) bahwa fungi mikoriza arbuskula yang diberikan bersimbiosis dengan akar tanaman dengan cara menginfeksi akar tanaman untuk mempermudah penyerapan unsur hara, fungi mikoriza arbuskula membentuk hifa yang dapat meningkatkan jangkauan tanaman dalam menyerap hara melalui sistem perakaran tanaman kelapa sawit. 


\section{Interaksi Pupuk Kompos dan Mikoriza}

Pengaruh interaksi antara pupuk kompos dan mikoriza berpengaruh nyata terhadap peubah diameter pangkal batang bibit kelapa sawit 30 HST (Tabel 3). Terdapat interaksi antara perlakuan $40 \%$ pupuk kompos $\left(\mathrm{K}_{2}\right)$ dengan perlakuan dosis mikoriza $0 \mathrm{~g} /$ polybag $\left(\mathrm{M}_{0}\right)$ terhadap ukuran diameter pangkal batamg bibit kelapa sawit terbesar, yaitu 11,88 $\mathrm{mm}$. Kondisi tersebut menunjukkan pertumbuhan sekunder batang bibit kelapa sawit pada perlakuan $40 \%$ pupuk kompos lebih agresif terutama tanpa aplikasi mikoriza dibandingkan dengan perlakuan yang menggunakan mikoriza pada setiap media tanam bibit yang diuji. Hal ini diduga terkait dengan asal bahan kompos yang digunakan, limbah pupuk kompos TKKS yang dipakai sebagai bahan baku kompos diduga masih belum steril dari residu minyak Crude Palm Oil (CPO). Residu minyak CPO yang masih mencemari bahan baku kompos ini telah mempengaruhi kemampuan kolonisasi fungi mikoriza arbuskula (FMA) di sekitar perakaran bibit kelapa sawit yang diuji. Menurut Firmansyah (2011), tandan kosong kelapa sawit masih mengandung residu minyak yang tergolong tinggi yakni $\pm 2,41 \%$.

\section{SIMPULAN DAN SARAN}

Pertumbuhan bibit kelapa sawit cenderung lebih baik dijumpai pada perlakuan $40 \%$ pupuk kompos.

Pertumbuhan bibit kelapa sawit terbaik dijumpai pada persentase akar terkolonisasi mikoriza pada perlakuan dosis mikoriza $20 \mathrm{~g} /$ polybag.

Interaksi Perlakuan kompos dengan aplikasi mikoriza arbuskula, berpengaruh nyata terhadap peubah diameter pangkal batang bibit kelapa sawit. Peubah diameter pangkal batang bibit kelapa sawit terbaik dijumpai pada kombinasi perlakuan kompos $40 \%$ dengan tanpa pemberian mikoriza.

Berdasarkan hasil penelitian disarankan melakukan penelitian lanjutan hingga bibit kelapa sawit umur 9-12 bulan dengan menggunakan jarak tanam. Dan sebaiknya dilakukan pada kondisi tanah yang sesuai untuk pengaplikasian mikoriza.

\section{DAFTAR PUSTAKA}

Balai Informasi Pertanian. 1990. Pedoman Budidaya Kelapa Sawit. Departemen Pertanian. Medan.

Deswenti, Eva. 2011. Pengaruh Campuran Tanah Lapisan Bawah (Subsoil) Dan Kompos Tandan Kosong Kelapa Sawit Sebagai Media Tanam Terhadap Pertumbuhan Bibit Kelapa Sawit (Elaeis Gueneensis Jacq) di Pembibitan Utama. Fakultas Pertanian Universitas Riau. Pekanbaru.

Direktorat Jenderal Perkebunan. 2017. Statistik Perkebunan Indonesia Komoditas Kelapa Sawit 2015-2017. Departemen Pertanian Republik Indonesia. Jakarta.

Firmansyah, A. M. 2011. Teknik Pembuatan Kompos. Kalimantan Tengah: Balai Pengkajian Teknologi Pertanian. 
Gardner, F.P., R.B. Peace dan R.L. Mitchell. 2001. Fisiologi Tanaman Budidaya (Edisi Terjemahan oleh Herawati Susilo dan Subiyanto) Jakarta: Universitas Indonesia Press 428.

Hamzah, T.M. A. 2011. Respon Bibit Kelapa Sawit (Elaeis guineensis Jacq.) pada Berbagai Dosis NPK Mutiara dan Mikoriza Vesikula Arbuskula. Skripsi. Fakultas Pertanian Universitas Syiah Kuala, Banda Aceh.

Harahap, R. A., C. Suherman dan S. Rosniawaty. 2014. Pemanfaatan fungi mikoriza arbuskular pada media campuran subsoil dan kompos kulit pisang terhadap pertumbuhan kelapa sawit (Elaeis gueneensis Jacq) varietas PPKS 540 di pembibitan awal. Agric.sci. 1 (4): 244 - 253.

Hendra, L.S. 2012. Pemberian Pupuk Majemuk dan Kompos Tandan Kosong Kelapa Sawit pada Media Tanam untuk Pertumbuhan Kelapa Sawit Di Main Nursery. Jom Faperta Vol. 2 No. 1

Husin, E, F dan R Marlis. 2002. Aplikasi cendawan mikoriza arbuskula sebagai pupuk biologi pada pembibitan tanaman kelapa sawit. Prosiding Seminar Nasional BKS PTN Wilayah Indonesia Barat. Fakultas Pertanian. Universitas Sumatera Utara. Medan.

Listyowati, M. S., S. Yusnaini, M. V. Rini, dan M.A.S. Aif. 2013. Pengaruh Sistem Olah Tanah dan Pemberian Mulsa Bagas terhadap Populasi Fungi Mikoriza Arbuskula pada Perkebunan Tebu. J. Agrotropika18(1): 16-20.

Novriani. 2010. Inokulasi Mikoriza Arbuskula Pada Bibit Kelapa Sawit (Elaeis guineensis Jacq.) yang Ditanam pada Berbagai Komposisi Media Tanam. AgronobiS Vol. 2 No. 4

Pusat Penelitian Kelapa Sawit (PPKS). 2008. Aplikasi Kompos Tandan Kosong Sawit (TKS) pada Lahan Perkebunan Kelapa Sawit TM. Pusat Penelitian Kelapa Sawit. Medan.

Same, M. 2011. Serapan phospat dan pertumbuhan bibit kelapa sawit pada tanah ultisol akibat cendawan mikoriza arbuskula. Jurnal Penelitian Pertanian Terapan. 11 (2): $69-76$.

Sukamto, ITN. 2008. 58 Kiat Meningkatkan Produktivitas dan Mutu Kelapa Sawit. Penebar Swadaya. Jakarta. 84 hal.

Sutarta. E.S, Winarna dan N.H. Darlan. 2005. "Peningkatan Efektivitas Pemupukan Melalui Aplikasi Kompos TKS Pada Pembibitan Kelapa Sawit". Prosiding Pertemuan Teknis Kelapa Sawit 2005: Peningkatan Produktivitas Kelapa Sawit Melalui Pemupukan dan Pemanfaatan Limbah PKS. Medan.

Treseder, K. K. 2013. The Extent of Mycorrhizal Colonization of Roots and its Influence on Plant Growth and Phosphorus Content. Plant Soil, 371, 1-13.

Widiastuti, H., E. Guhardja, N. Sukarno, L. K Darusman, D. H Gunadi, dan S. Smith. 2003. Aktivitas Fosfatase dan Produksi Asam Organik di Rhizosfer Bibit Kelapa Sawit Bermikoriza, Menara Perkebunan 71 (2) : 64-74. 